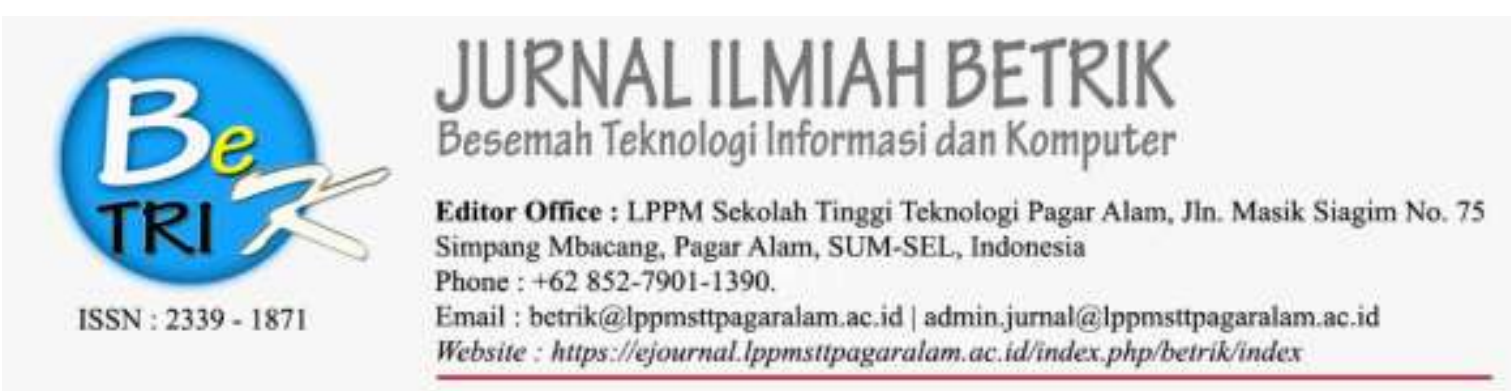

\title{
SISTEM MONITORING SISWA PADA SD METHODIST-5 KOTA PAGAR ALAM BERBASIS WEB
}

\author{
Siti Aminah \\ Dosen Sekolah Tinggi Teknologi Pagar Alam \\ Jalan Masik Siagim No.75 Simpang Mbacang Kec.Dempo Tengah Kota Pagar Alam \\ Sur-el : mbameena@gmail.com ${ }^{1}$
}

\begin{abstract}
$\overline{\text { Abstract:Student Monitoring System is a method or system that aims to monitor the }}$ pattern of student development in school. Growing advances in information technology today, schools need to promote themselves through the school website so that people can access all school information easily, especially to monitor the development of children in school. System development method used in the design of Student Monitoring System is to use waterfall method or waterfall.With this student monitoring system, the guardian of student can know result of student learning evaluation which have been reached in school like student development which is result of evaluation of study of per-week and student value which is result of evaluation of study per-semester.So, it is expected that the guardians can be more easily in monitoring the development of their children in school so that the guardians can know the results of student learning evaluations that have been achieved in school.
\end{abstract}

Keywords: Student Monitoring System, Waterfall, Website.

\begin{abstract}
Abstrak:Sistem Monitoring Siswa merupakan suatu metode atau sistem yang bertujuan untuk melakukan pengawasan terhadap pola perkembangan siswa di sekolah. Berkembangnya kemajuan teknologi informasi saat ini, sekolah perlu mempromosikan dirinya melalui website sekolah sehingga masyarakat dapat mengakses segala informasi sekolah dengan mudah terutama untuk melakukan monitoring perkembangan anak di sekolah. Metode pengembangan sistem yang digunakan dalam perancangan Sistem Monitoring Siswa ini ialah menggunakan metode waterfall atau air terjun. Dengan adanya Sistem Monitoring Siswa ini, para wali murid dapat mengetahui hasil evaluasi belajar siswa yang telah dicapai di sekolah seperti perkembangan siswa yang merupakan hasil evaluasi belajar per- minggu dan nilai siswa yang merupakan hasil evaluasi belajar per-semester. Jadi, diharapkan para wali murid dapat menjadi lebih mudah dalam mengawasi perkembangan anak mereka di sekolah sehingga para wali murid dapat mengetahui hasil evaluasi belajar siswa yang telah dicapai di sekolah.
\end{abstract}

Kata Kunci: Sistem Monitoring Siswa, Waterfall, Website.

\section{PENDAhULUAN}

Teknologi mampu memberikan inovasi dan pembaharuan yang bisa dimanfaatkan untuk memenuhi kebutuhan manusia, khususnya sistem informasi. Menurut (Kadir, Abdul, 2003, p. 11), Hall menjelaskan sistem informasi adalah sebuah rangkaian prosedur formal di mana data dikelompokkan, diproses 
menjadi informasi, dan didistribusikan kepada pemakai. Oleh karena itu, sistem informasi dapat meningkatkan efektivitas dan efisiensi orang-orang yang bekerja dalam suatu tempat yang dapat memungkinkan pengaksesan informasi dengan jumlah yang sangat besar namun dalam ruang yang kecil.

Berdasarkan hasil wawancara mengenai Sistem Monitoring Siswa SD Methodist-5 Pagar Alam didapatkan informasi bahwa monitoring terhadap siswa yang berjalan selama ini masih menggunakan laporan harian yang dibuat oleh Guru Kelas. Jadi, Guru Kelas menulis tangan form capaian pembelajaran setiap siswa dan nantinya diserahkan kepada Wali Kelas, kemudian form capaian pembelajaran tersebut diserahkan kembali ke bagian Tata Usaha (TU) untuk diketik menggunakan Microsoft Excel. Sistem Monitoring Siswa yang dilakukan selama ini yaitu wali murid harus datang terlebih dahulu ke sekolah untuk mengetahui perkembangan anak mereka selama mengikuti proses belajar di sekolah.

Dari latar belakang masalah diatas maka didapatkan rumusan masalah mengenai "Sistem Monitoring Siswa pada SD Methodist-5 Kota Pagar Alam Berbasis Web" yaitu "Bagaimana merancang dan membangun Sistem Monitoring Siswa pada SD Methodist5 Kota Pagar Alam Berbasis Web?".

Penelitianinibertujuanuntukmerancang dan membangun Sistem Monitoring Siswa pada SD Methodist-5 Kota Pagar Alam Berbasis Web .

\section{METODOLOGI PENELITIAN}

\subsection{Waktu dan Tempat Penelitian}

Lokasi penelitian beralamat di Jalan Kampung Melati No.723A Kota Pagar Alam yang telah dilaksanakan pada Oktober 2016 sampai dengan Juni 2017.

\subsection{Metode Pengumpulan Data}

Hal pertama yang dilakukan dalam analisis sistem adalah melakukan pengumpulan data (Rosa A.S, M.Shalahuddin, 2014, pp. 19-21). Ada beberapa teknik pengumpulan data yang sering dilakukan yaitu:

\section{Teknik Observasi}

Teknik observasi ini merupakan teknik mengumpulkan data informasi dengan cara meninjau dan mengamati secara langsung kegiatan di SD Methodist-5 Pagar Alam.

\section{Teknik Wawancara}

Wawancara merupakan percakapan antara dua orang atau lebih yang berlangsung antara narasumber dan pewawancara. Tujuan dari wawancara adalah untuk mengumpulkan data dari hasil wawancara secara langsung dengan pihak Kepala Sekolah, Wali Kelas, Staf Tata Usaha (TU) dan Wali Murid yang terkait dengan pembuatan penelitian ini.

\section{Studi Pustaka}

Teknik pengumpulan data studi pustaka merupakan teknik pengumpulan data yang diambil dari berbagai sumber seperti buku, jurnal, dan media internet yang berkaitan dengan pembuatan Sistem Monitoring Siswa.

\section{Dokumentasi}

Teknik pengumpulan data dokumentasi merupakan teknik pengumpulan data yang 
dilakukan dengan cara menggunakan data-data yang telah diperoleh dari sekolah seperti data siswa maupun arsip-arsip yang berkaitan dengan pembuatan Sistem Monitoring Siswa.

\subsection{Metode Pengembangan Sistem}

Model Waterfall atau air terjun, kadangkadang sisebut Classic Live-Cycle, menunjukkan pendekatan, sistematis sekuensial untuk pengembangan perangkat lunak yang dimulai dengan spesifikasi pelanggan persyaratan dan berlangsung melalui perencanaan konstruksi, pemodelan dan penyebaran, yang berpuncak pada dukungan terus-menerus dari perangkat lunak selesai. (Rohmat Taufik, ST., M.Kom, 2013, pp. 173-174).

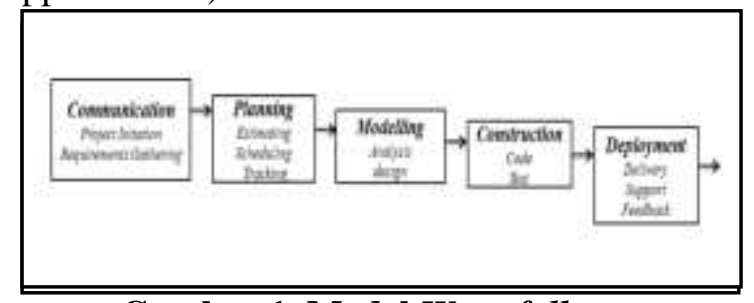

Gambar 1. Model Waterfall

\section{a. Communication/Komunikasi}

Pemodelan ini diawali dengan mencari kebutuhan dari keseluruhan sistem yang akan diaplikasikan ke dalam bentuk perangkat lunak.

\section{b. Planning/Rencana}

Proses ini digunakan untuk menentukan jadwal/waktu yang diperlukan untuk menyelesaikan setiap kegiatan yang dibutuhkan untuk menyelesaikan proyek perangkat lunak ini.

\section{c. Modeling/Pemodelan}

Proses ini digunakan untuk mengubah kebutuhan-kebutuhan diatas menjadi representasi ke dalam bentuk "blueprint" perangkat lunak sebelum coding dimulai.

\section{d. Contruction/Konstruksi}

Untuk dapat dimengerti oleh mesin, dalam hal ini adalah komputer, maka desain tadi harus diubah bentuknya menjadi bentuk yang dapat dimengerti oleh mesin, yaitu kedalam bahasa pemrograman melalui proses coding.

e. Deployment/Penyebaran

Aplikasi yang sudah jadi segera di antar ke pengguna atau pemilik sistem, selain di antar maka secara otomatis pemeliharaan suatu perangkat lunak diperlukan.

\subsection{Sistem Informasi}

Sistem informasi yang menggunakan komputer biasa disebut sistem informasi berbasis komputer (Computer Based Information System atau CBIS). Dari definisi tersebut, dapat disimpulkan bahwa sistem informasi mencakup sejumlah komponen (manusia, komputer, teknologi informasi, dan prosedur kerja), ada sesuatu yang diproses (data menjadi informasi) dan dimaksudkan untuk mencapai suatu sasaran atau tujuan. (Kadir, Abdul, 2003, p. 10).

\subsection{Sistem Monitoring}

Menurut (Nelly Indriani Widiastuti, Rani Susanto) Sistem monitoring atau sistem pengawasan adalah suatu upaya yang sistematik untuk menetapkan kinerja standar pada perencanaan untuk merancang sistem umpan balik informasi, untuk membandingkan kinerja aktual dengan standar yang telah terjadi suatu penyimpangan tersebut, serta untuk mengambil tindakan perbaikan yang diperlukan untuk menjamin bahwa semua sumber daya perusahaan atau organisasi telah 
digunakan secara efektif dan efisien mungkin guna mencapai tujuan perusahaan atau organisasi. Menurut (Nelly Indriani Widiastuti, Rani Susanto, p. 196) monitoring adalah proses pengumpulan dan analisis informasi berdasarkan indikator yang ditetapkan secara sistematis dan kontinu tentang kegiatan/program sehingga dapat dilakukan tindakan koreksi untuk penyempurnaan program/kegiatan itu selanjutnya.

\section{$2.6 \quad W e b$}

Webadalah salah satu aplikasi yang berisikan dokumen-dokumen multimedia (text, gambar, suara, animasi, video) di dalamnya yang menggunakan protocol HTTP (Hypertext transfer protocol) dan untuk mengaksesnya mengunakan perangkat lunak yang disebut browser. Browser (perambah) adalah aplikasi yang mampu menjalankan dokumen-dokumen web dengan cara diterjemahkan. Prosesnya dilakukan oleh komponen yang terdapat di dalam aplikasi browser yang biasa disebut web engine. Semua dokumen web ditampilkan oleh browser dengan cara diterjemahkan. (Arief, M. Rudyanto, 2011, pp. 7-8).

\subsection{Pemrograman PHP}

PHP (PHP: Hypertext Preprocessor) adalah bahasa server-side scripting yang menyatu dengan HTML untuk membuat halaman web yang dinamis. Karena PHP merupakan server-side scripting maka sintaks dan perintah-perintah $P H P$ akan dieksekusi di server kemudian hasilnya dikirimkan ke browser dalam format HTML. Dengan demikian kode program yang ditulis dalam PHP tidak akan terlihat oleh user sehingga keamanan halaman web lebih terjamin.

Salah satu keunggulan yang dimiliki oleh PHP adalah kemampuannya untuk melakukan koneksi ke berbagai macam software sistem manajemen basis data/Database Management System (DBMS), sehingga dapat menciptakan suatu haaman web yang dinamis. (Arief, M. Rudyanto, 2011, p. 43).

\subsection{Database MySQL}

MySQL merupakan database yang pertama kali didukung oleh bahasa pemrograman script untuk internet $(P H P$ dan Perl). MySQL lebih sering digunakan untuk membangun aplikasi berbasis web, umumnya pengembangan aplikasinya menggunakan bahasa pemrograman script PHP. MySQL termasuk RDBMS (Relational Database Management System). Itulah sebabnya istilah tabel, baris, dan kolom digunakan pada MySQL. Pada MySQL, sebuah database mengandung satu atau sejumlah tabel. Tabel terdiri atas sejumlah kolom dan baris, dimana setiap kolom berisi sekumpulan data yang memiliki tipe yang sejenis, dan baris merupakan sekumpulan data yang saling berkaitan dan membentuk informasi. Kolom biasanya juga disebut sebagai field dan informasi yang tersimpan dalam setiap baris disebut record. (Arief, M. Rudyanto, 2011, pp. 152-153).

\subsection{UML (Unified Modelling Language) \\ Pada perkembangan teknik} pemrograman berorientasi objek, muncullah 
sebuah standarisasi bahasa pemodelan untuk pembangunan perangkat lunak yang dibangun denganmenggunakan teknik pemrograman berorientasi objek, yaitu Unified Modelling Language (UML). UML adalah salah satu standar bahasa yang banyak digunakan di dunia industri untuk mendefinisikan requirement, membuat analisis dan desain, serta menggambarkan arsitektur dalam pemrograman berorientasi objek. UML muncul karena adanya kebutuhan pemodelan visual untuk menspesifikasikan, menggambarkan, membangun, dan dokumentasi dari sistem perangkat lunak. UML merupakan bahasa visual untuk pemodelan dan komunikasi mengenai sebuah sistem dengan menggunakan diagram dan teks-teks pendukung. UML hanya berfungsi untuk melakukan pemodelan. Jadi penggunaan $U M L$ tidak terbatas pada metodologi tertentu, meskipun pada kenyataannya $U M L$ paling banyak digunakan pada metodologi berorientasi objek. (Rosa A.S, M.Shalahuddin, 2014, pp. 137-138).

\subsection{Struktur Tabel}

Menurut (Rosa A.S, M.Shalahuddin, 2014, p. 43) menjelaskan bahwa sistem basis data adalah sistem terkomputerisasi yang tujuan utamanya adalah memelihara data yang sudah diolah atau informasi dan membuat informasi tersedia saat dibutuhkan. Data dalam database biasanya saling terelasional antara satu dengan lainnya.

\subsubsection{Tabel Perkembangan}

Tabel 1. Tabel Perkembangan

\begin{tabular}{cllll}
\hline No & Name & Type & Size & \multicolumn{1}{c}{ Ket } \\
\hline 1. & id_user* $^{*}$ & int & 10 & Id User \\
\hline 2. & nis & int & 10 & $\begin{array}{l}\text { Nomor } \\
\text { Induk Siswa }\end{array}$ \\
\hline
\end{tabular}

\begin{tabular}{|c|c|c|c|c|}
\hline No & Name & Tyре & Size & Ket \\
\hline 3. & nama & $\begin{array}{l}\text { varch } \\
\text { ar }\end{array}$ & 50 & Nama Siswa \\
\hline 4. & $\operatorname{tg} 1$ & date & & Tanggal \\
\hline 5. & kelas & $\begin{array}{l}\text { varch } \\
\text { ar }\end{array}$ & 5 & Kelas Siswa \\
\hline 6. & Catatan & Text & & $\begin{array}{l}\text { Keterangan } \\
\text { Mengenai } \\
\text { Siswa }\end{array}$ \\
\hline 7. & Agama & $\begin{array}{l}\text { varch } \\
\text { ar }\end{array}$ & 5 & Nilai Agama \\
\hline 8. & Pkn & $\begin{array}{l}\text { varch } \\
\text { ar }\end{array}$ & 5 & $\begin{array}{l}\text { Nilai } \\
\text { Pendidikan } \\
\text { Kewarganeg } \\
\text { araan } \\
\end{array}$ \\
\hline 9. & bindo & $\begin{array}{l}\text { varch } \\
\text { ar }\end{array}$ & 5 & $\begin{array}{l}\text { Nilai Bahasa } \\
\text { Indonesia }\end{array}$ \\
\hline 10. & mtk & $\begin{array}{l}\text { varch } \\
\text { ar }\end{array}$ & 5 & $\begin{array}{l}\text { Nilai } \\
\text { Matematika }\end{array}$ \\
\hline 11. & ipa & $\begin{array}{l}\text { varch } \\
\text { ar }\end{array}$ & 5 & $\begin{array}{l}\text { Nilai Ilmu } \\
\text { Pengetahuan } \\
\text { Alam }\end{array}$ \\
\hline 12. & ips & $\begin{array}{l}\text { varch } \\
\text { ar }\end{array}$ & 5 & $\begin{array}{l}\text { Nilai I lmu } \\
\text { Pengetahuan } \\
\text { Sosial }\end{array}$ \\
\hline 13. & sbk & $\begin{array}{l}\text { varch } \\
\text { ar }\end{array}$ & 5 & $\begin{array}{l}\text { Nilai Seni } \\
\text { Budaya dan } \\
\text { Kesenian }\end{array}$ \\
\hline 14. & penjas & $\begin{array}{l}\text { varch } \\
\text { ar }\end{array}$ & 5 & Nilai Penjas \\
\hline 15. & bing & $\begin{array}{l}\text { varch } \\
\text { ar }\end{array}$ & 5 & $\begin{array}{l}\text { Nilai Bahasa } \\
\text { Inggris }\end{array}$ \\
\hline 16. & tik & $\begin{array}{l}\text { varch } \\
\text { ar }\end{array}$ & 5 & $\begin{array}{l}\text { Nilai } \\
\text { Teknologi } \\
\text { Informasi }\end{array}$ \\
\hline
\end{tabular}

*Primary Key

\subsubsection{Tabel Nilai}

Tabel 2. Tabel Nilai

\begin{tabular}{|c|c|c|c|c|}
\hline No. & Name & Type & Size & Ket \\
\hline 1. & id_user* & int & 10 & Id User \\
\hline 2. & nis & int & 10 & $\begin{array}{l}\text { Nomor } \\
\text { Induk Siswa }\end{array}$ \\
\hline 3. & nama & $\begin{array}{l}\text { varch } \\
\text { ar }\end{array}$ & 50 & Nama Siswa \\
\hline 4. & semester & $\begin{array}{l}\text { varch } \\
\text { ar }\end{array}$ & 5 & $\begin{array}{l}\text { Semester } \\
\text { Siswa }\end{array}$ \\
\hline 5. & kelas & $\begin{array}{l}\text { varch } \\
\text { ar }\end{array}$ & 5 & Kelas Siswa \\
\hline 6. & catatan & text & & Catatan \\
\hline 7. & agama & $\begin{array}{l}\text { varch } \\
\text { ar }\end{array}$ & 5 & Nilai Agama \\
\hline 8. & pkn & $\begin{array}{l}\text { varch } \\
\text { ar }\end{array}$ & 5 & $\begin{array}{l}\text { Nilai } \\
\text { Pendidikan } \\
\text { Kewarganeg } \\
\text { araan }\end{array}$ \\
\hline 9. & bindo & $\begin{array}{l}\text { varch } \\
\text { ar }\end{array}$ & 5 & $\begin{array}{l}\text { Nilai Bahasa } \\
\text { Indonesia }\end{array}$ \\
\hline
\end{tabular}




\begin{tabular}{|c|c|c|c|c|}
\hline No. & Name & Type & Size & Ket \\
\hline 10. & mtk & $\begin{array}{l}\text { varch } \\
\text { ar }\end{array}$ & 5 & $\begin{array}{l}\text { Nilai } \\
\text { Matematika }\end{array}$ \\
\hline 11. & ipa & $\begin{array}{l}\text { varch } \\
\text { ar }\end{array}$ & 5 & $\begin{array}{l}\text { Nilai Ilmu } \\
\text { Pengetahuan } \\
\text { Alam }\end{array}$ \\
\hline 12. & ips & $\begin{array}{l}\text { varch } \\
\text { ar }\end{array}$ & 5 & $\begin{array}{l}\text { Nilai I lmu } \\
\text { Pengetahuan } \\
\text { Sosial }\end{array}$ \\
\hline 13. & sbk & $\begin{array}{l}\text { varch } \\
\text { ar }\end{array}$ & 5 & $\begin{array}{l}\text { Nilai Seni } \\
\text { Budaya dan } \\
\text { Kesenian }\end{array}$ \\
\hline 14. & penjas & $\begin{array}{l}\text { varch } \\
\text { ar }\end{array}$ & 5 & Nilai Penjas \\
\hline 15. & bing & $\begin{array}{l}\text { varch } \\
\text { ar }\end{array}$ & 5 & $\begin{array}{l}\text { Nilai Bahasa } \\
\text { Inggris }\end{array}$ \\
\hline 16. & tik & $\begin{array}{l}\text { varch } \\
\text { ar }\end{array}$ & 5 & $\begin{array}{l}\text { Nilai } \\
\text { Teknologi } \\
\text { Informasi }\end{array}$ \\
\hline 17. & sikap & $\begin{array}{l}\text { varch } \\
\text { ar }\end{array}$ & 5 & $\begin{array}{l}\text { Penilaian } \\
\text { Sikap }\end{array}$ \\
\hline 18. & $\begin{array}{l}\text { kerajiana } \\
\mathrm{n}\end{array}$ & $\begin{array}{l}\text { varch } \\
\text { ar }\end{array}$ & 5 & $\begin{array}{l}\text { Penilaian } \\
\text { Kerajianan }\end{array}$ \\
\hline 19. & kerapian & $\begin{array}{l}\text { varch } \\
\text { ar }\end{array}$ & 5 & $\begin{array}{l}\text { Penilaian } \\
\text { Kerapian }\end{array}$ \\
\hline 20. & izin & $\begin{array}{l}\text { varch } \\
\text { ar }\end{array}$ & 5 & Jumlah Izin \\
\hline 21. & sakit & $\begin{array}{l}\text { varch } \\
\text { ar }\end{array}$ & 5 & Jumlah Sakit \\
\hline 22. & tanpa & $\begin{array}{l}\text { varch } \\
\text { ar }\end{array}$ & 5 & $\begin{array}{l}\text { Jumlah } \\
\text { Tanpa } \\
\text { Keterangan }\end{array}$ \\
\hline
\end{tabular}

*Primary Key

\subsection{Desain Storyboard}

\subsubsection{Desain Halaman Monitoring}

Desain halaman Sistem Monitoring Siswa merupakan tampilan awal Sistem Monitoring Siswa SD Methodist-5 Pagar Alam. Desain halaman Sistem Monitoring Siswa dapat dilihat seperti gambar dibawah ini:

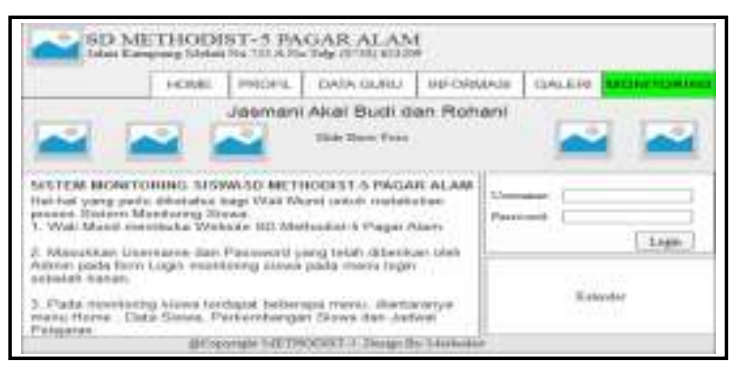

Gambar 2. Desain Halaman Sistem Monitoring Siswa

\subsubsection{Desain Halaman Monitoring Perkembangan Siswa}

Desain halaman perkembangan siswa merupakan tampilan ketika orang tua melihat perkembangan siswa SD Methodist-5 Pagar Alam yang mencakup hasil evaluasi belajar per minggu. Desain halaman perkembangan siswa dapat dilihat seperti gambar dibawah ini:

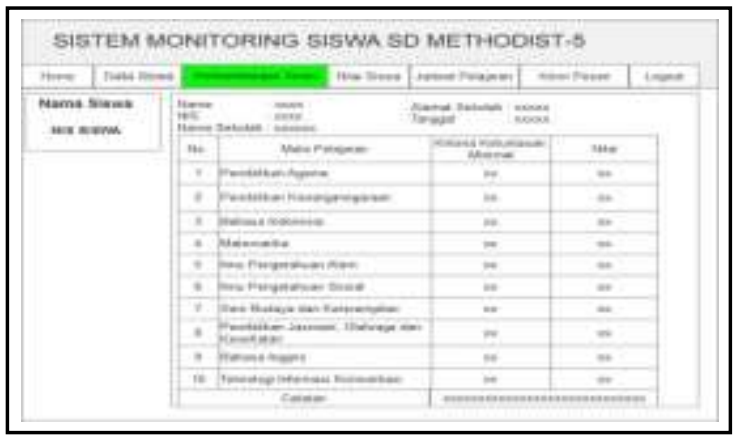

Gambar 3. Desain Halaman Perkembangan Siswa

\subsubsection{Desain Halaman Monitoring Nilai} Siswa

Desain halaman nilai siswa merupakan tampilan ketika orang tua melihat nilai siswa SD Methodist-5 Pagar Alam yang mencakup penilaian siswa per semester. Desain halaman nilai siswa dapat dilihat seperti gambar dibawah ini:

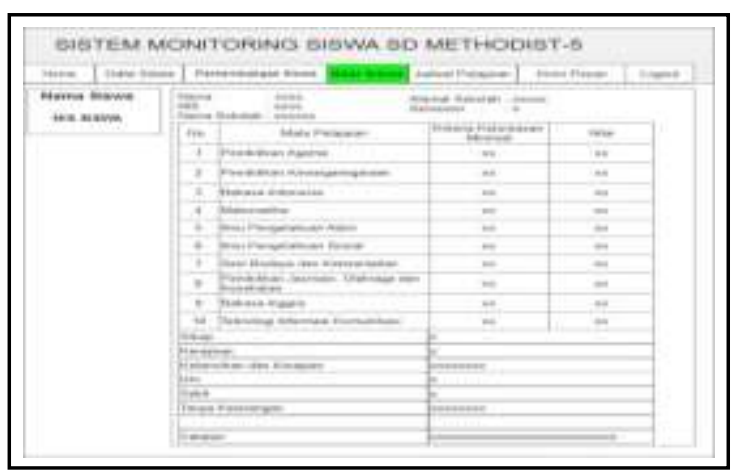

Gambar 4. Desain Halaman Nilai Siswa 
2.11.4 Desain Halaman Input

\section{Perkembangan Siswa}

Desain halaman input perkembangan siswa merupakan tampilan wali kelas untuk mengisi perkembangan siswa. Desain halaman input perkembangan siswa dapat dilihat seperti gambar dibawah ini:

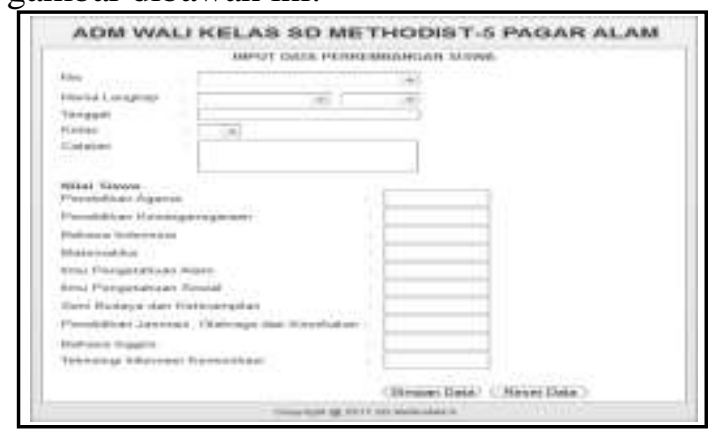

\section{Gambar 5. Desain Halaman Input PerkembanganSiswa}

\subsubsection{Desain Halaman Lihat Perkembangan Siswa}

Halaman lihat perkembangan siswa adalah halaman untuk melihat perkembangan siswa atas hasil evaluasi hasil capaian pembelajaran siswa per minggu. Desain halamanlihatperkembangan siswa dapat dilihat seperti gambar dibawah ini:

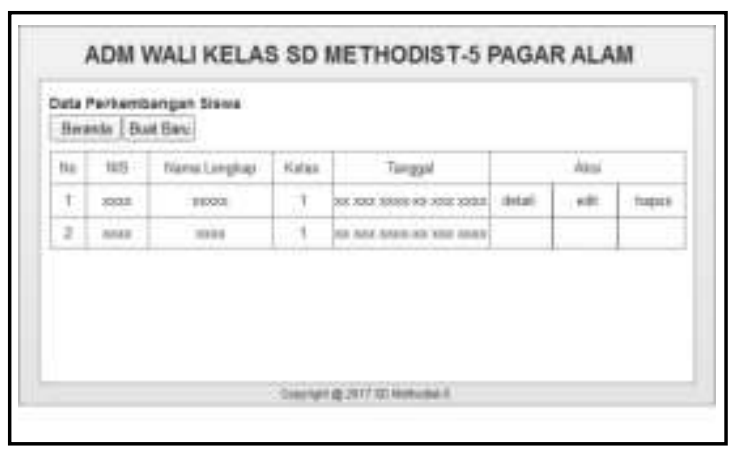

\section{Gambar 6. Desain Halaman Lihat Perkembangan Siswa}

\subsubsection{Desain Halaman Input Nilai Siswa \\ Desain halaman input nilai siswa} merupakan tampilan wali kelas untuk mengisi nilai siswa. Desain halaman input nilai siswa dapat dilihat seperti gambar dibawah ini:

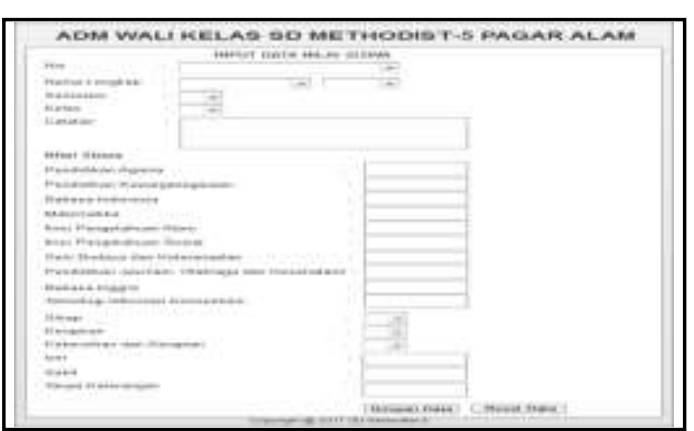

Gambar 7. Desain Halaman Input NilaiSiswa 2.11.7 Desain Halaman Lihat Nilai Siswa

Halaman lihat nilai siswa adalah halaman untuk melihat nilai siswa atas hasil evaluasi pembelajaran yang telah dicapai di sekolah per semester. Desain halaman lihatnilaisiswa dapat dilihat seperti gambar dibawah ini:

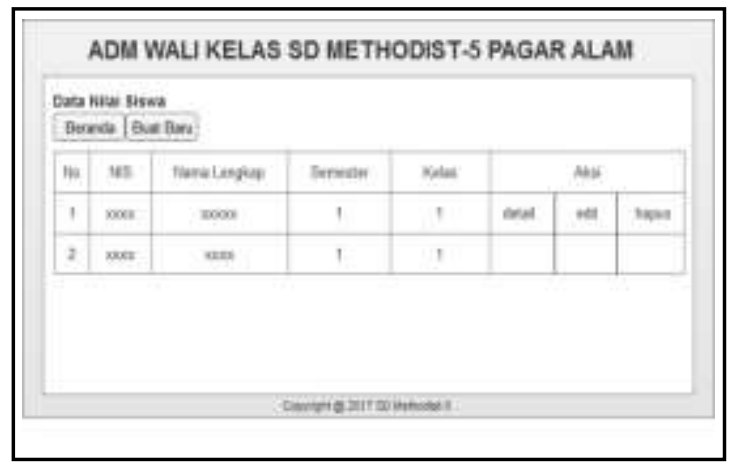

Gambar 8. Desain Halaman Lihat NilaiSiswa

\section{HASIL DAN PEMBAHASAN}

\subsection{HASIL}

Pada bab ini peneliti merancang dan membuat sistem monitoring siswa pada SD Methodist-5 Kota Pagar Alam yang dapat membantu pihak sekolah SD Methodist-5 dalam mengelola data siswa di sekolah dan juga mempermudah proses pengawasan orang tua terhadap siswa atas hasil evaluasi belajar siswa yang telah dicapai di sekolah seperti halnya hasil evaluasi belajar per-minggu dan per-semester. Para wali murid dapat mengontrol anak-anak mereka disekolah 
dengan menggunakan website sekolah yang tehubung ke jaringan internet sehingga para wali murid tidak harus datang ke sekolah dan menemui wali kelas secara langsung. Implementasi sistem merupakan langkahlangkah atau prosedur-prosedur yang dilakukan dalam menyelesaikan desain sistem yang telah di setujui, untuk menguji, menginstal dan memulai sistem baru untuk memperbaiki sistem yang telah berjalan selama ini.

Pengujian yang dilakukan oleh Wali Kelas pada fungsionalitas dan antarmuka sistem menunjukkan keberhasilan sistem sesuai dengan kriteria pengujian, ditunjukkan dengan hasil dibawah ini :

Tabel 3. Tabel Pengujian Wali Kelas

\begin{tabular}{|c|c|c|c|}
\hline No. & $\begin{array}{c}\text { Kriteria Hasil } \\
\text { Pengujian }\end{array}$ & Ya & Tidak \\
\hline 1. & $\begin{array}{l}\text { Sistem mampu untuk } \\
\text { melakukan } \\
\text { pengelolaan data nilai } \\
\text { siswa }\end{array}$ & $\checkmark$ & \\
\hline 2. & $\begin{array}{l}\text { Sistem mampu untuk } \\
\text { melakukan } \\
\text { pengelolaan data } \\
\text { perkembangan siswa }\end{array}$ & $\checkmark$ & \\
\hline 3. & $\begin{array}{l}\text { Sistem dapat } \\
\text { menampilkan hasil } \\
\text { dari data nilai siswa }\end{array}$ & $\checkmark$ & \\
\hline 4. & $\begin{array}{l}\text { Sistem dapat } \\
\text { menampilkan hasil } \\
\text { dari data } \\
\text { perkembangan siswa }\end{array}$ & $\checkmark$ & \\
\hline 5. & $\begin{array}{l}\text { Sistem mampu } \\
\text { memberikan } \\
\text { kemudahan dalam } \\
\text { melakukan } \\
\text { pengelolaan data nilai } \\
\text { siswa }\end{array}$ & $\checkmark$ & \\
\hline 6. & $\begin{array}{l}\text { Sistem mampu } \\
\text { memberikan } \\
\text { kemudahan dalam } \\
\text { melakukan } \\
\text { pengelolaan data } \\
\text { perkembangan siswa }\end{array}$ & $\checkmark$ & \\
\hline 7. & $\begin{array}{l}\text { Tampilan web } \\
\text { nyaman bagi }\end{array}$ & $\checkmark$ & \\
\hline
\end{tabular}

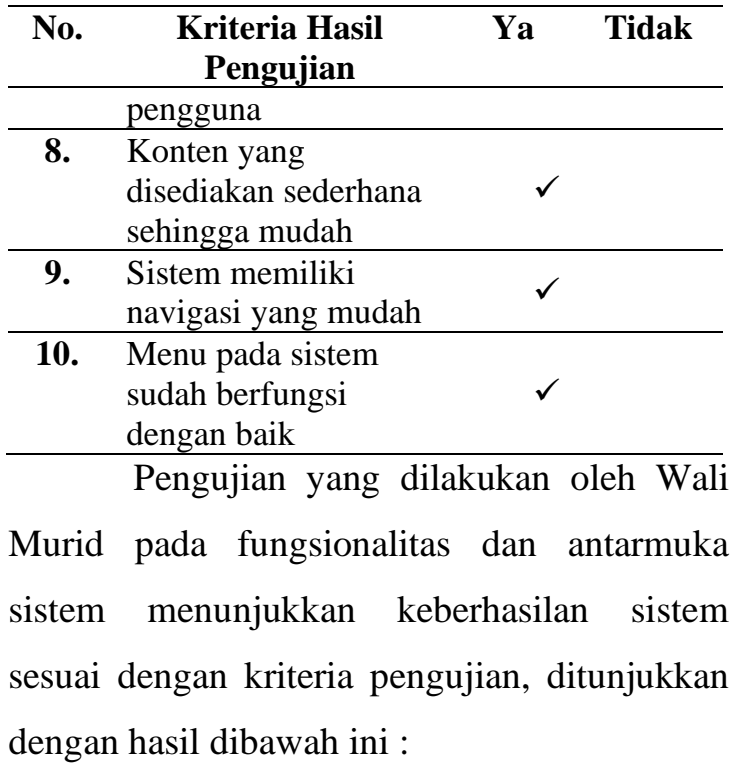

Tabel 4. Tabel Pengujian Wali Murid

\begin{tabular}{|c|c|c|c|}
\hline No. & $\begin{array}{c}\text { Kriteria Hasil } \\
\text { Pengujian }\end{array}$ & Ya & Tidak \\
\hline 1. & $\begin{array}{l}\text { Sistem mampu untuk } \\
\text { melakukan login } \\
\text { monitoring }\end{array}$ & $\checkmark$ & \\
\hline 2. & $\begin{array}{l}\text { Sistem mampu untuk } \\
\text { menampilkan } \\
\text { halaman utama } \\
\text { monitoring }\end{array}$ & $\checkmark$ & \\
\hline 3. & $\begin{array}{l}\text { Sistem mampu untuk } \\
\text { menampilkan data } \\
\text { siswa }\end{array}$ & $\checkmark$ & \\
\hline 4. & $\begin{array}{l}\text { Sistem dapat } \\
\text { menampilkan } \\
\text { perkembangan siswa }\end{array}$ & $\checkmark$ & \\
\hline 5. & $\begin{array}{l}\text { Sistem dapat } \\
\text { menampilkan nilai } \\
\text { siswa }\end{array}$ & $\checkmark$ & \\
\hline 6. & $\begin{array}{l}\text { Sistem dapat } \\
\text { menampilkan jadwal } \\
\text { pelajaran }\end{array}$ & $\checkmark$ & \\
\hline 7. & $\begin{array}{l}\text { Tampilan web } \\
\text { nyaman bagi } \\
\text { pengguna }\end{array}$ & $\checkmark$ & \\
\hline 8. & $\begin{array}{l}\text { Konten yang } \\
\text { disediakan } \\
\text { sederhana sehingga } \\
\text { mudah }\end{array}$ & $\checkmark$ & \\
\hline 9. & $\begin{array}{l}\text { Sistem memiliki } \\
\text { navigasi yang mudah }\end{array}$ & $\checkmark$ & \\
\hline 10. & $\begin{array}{l}\text { Menu pada sistem } \\
\text { sudah berfungsi } \\
\text { dengan baik }\end{array}$ & $\checkmark$ & \\
\hline
\end{tabular}




\subsection{PEMBAHASAN}

Batasan dari website sistem monitoring siswa ini hanya sebatas penginputan data profil, data guru, informasi, galeri, dan monitoring, perbaikan data dan hapus data. Adapun cara untuk menjalankan sistem monitoring siswa ini yaitu dengan mengisi http://methodist5.esy.es/monitoring/pada

kolom pencarian browseryang kemudian akan menampilkan website sistem monitoring SD Methodist-5 kota Pagar Alam yang memiliki menu pilihan diantaranya yaitu Home, Profil, Data Guru, Informasi, Galeri dan Monitoring.

\subsubsection{Desain Halaman Monitoring}

Halaman monitoring merupakan halaman yang berisikan langkah-langkah yang harus dilakukan orang tua siswa dalam melakukan kegiatan monitoring. Berikut gambar tampilannya:

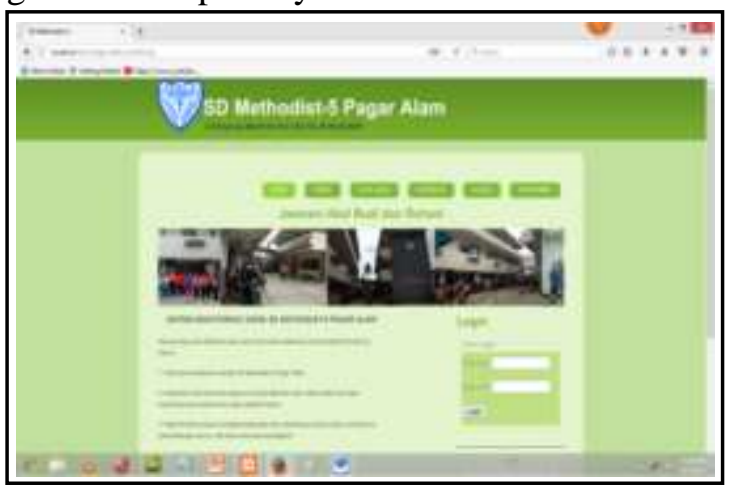

Gambar 9. Desain Halaman Monitoring

\subsubsection{Desain Halaman Monitoring \\ Perkembangan Siswa}

Halaman monitoring data siswa merupakan halaman yang berisikan data perkembangan siswa SD Methodist-5 kota Pagar Alam atas hasil evaluasi hasil capaian pembelajaran siswa per minggu. Berikut gambar tampilannya:

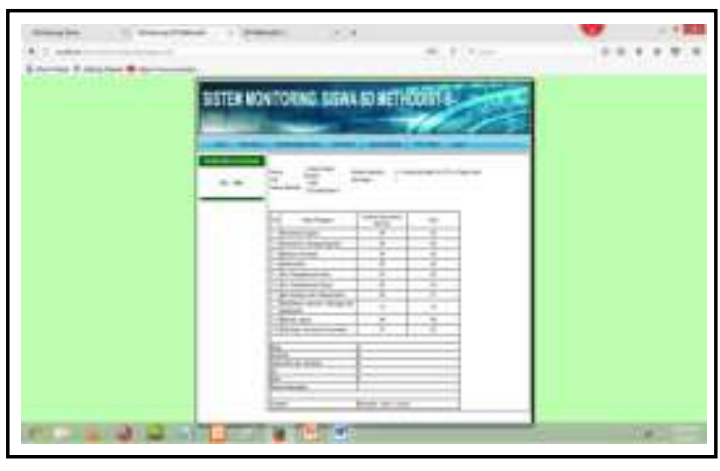

Gambar 10. Desain Halaman Monitoring

\section{Perkembangan Siswa}

\subsubsection{Desain Halaman Monitoring Nilai} Siswa

Halaman monitoring data siswa merupakan halaman yang berisikan data nilai siswa SD Methodist-5 kota Pagar Alam atas hasil evaluasi pembelajaran per semester. Berikut gambar tampilannya:

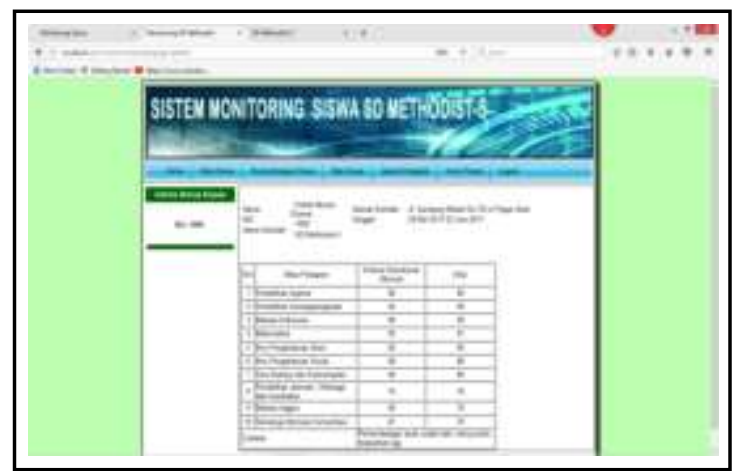

Gambar 11. Desain Halaman Monitoring

\section{Nilai Siswa}

\subsubsection{Desain Halaman Input \\ Perkembangan Siswa \\ Halaman input perkembangan siswa} adalah halaman untuk menambah data perkembangan siswa atas hasil evaluasi pembelajaran di sekolah per minggu. NIS dan nama pada input perkembangan siswa secara otomatis muncul sesuai dengan id user, karena sebelumnya sudah ditambahkan terlebih dahulu ke data siswa. Jadi pada input 
perkembangan siswa bisa langsung dipilihtanpa harus mengetikkan NIS dan nama lagi. Berikut gambar tampilannya :

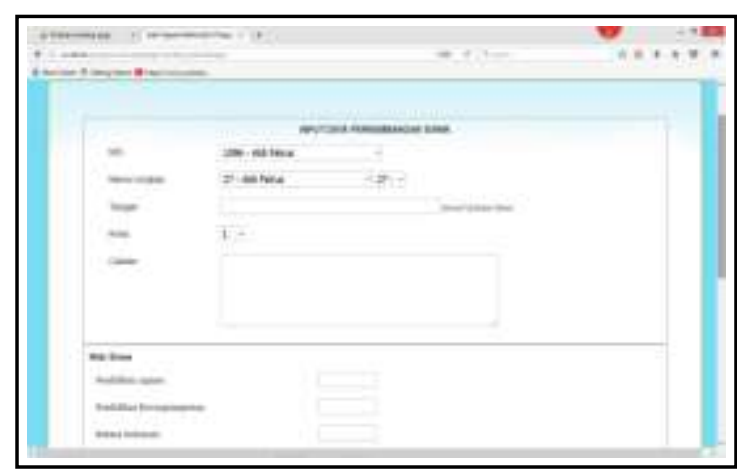

Gambar 12. Desain Halaman Input

\section{Perkembangan Siswa}

\subsubsection{Desain}

Halaman

Lihat

\section{Perkembangan Siswa}

Halaman lihat perkembangan siswa adalah halaman untuk melihat perkembangan siswa atas hasil evaluasi hasil capaian pembelajaran siswa per minggu. Berikut gambar tampilannya:

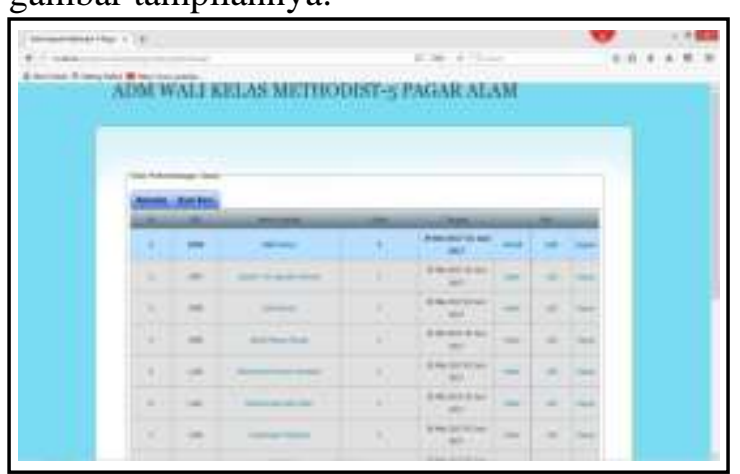

Gambar 13. Desain Halaman Lihat Perkembangan Siswa

\subsubsection{Desain Halaman Input Nilai Siswa}

Halaman input nilai siswa adalah halaman untuk menambah nilai siswa atas hasil evaluasi pembelajaran yang telah dicapai di sekolah per semester. NIS dan nama pada input nilai siswa secara otomatis muncul sesuai dengan id user, karena sebelumnya sudah ditambahkan terlebih dahulu ke data siswa. Jadi pada input nilai siswa bisa langsung dipilih tanpa harus mengetikkan NIS dan nama lagi Berikut gambar tampilannya :

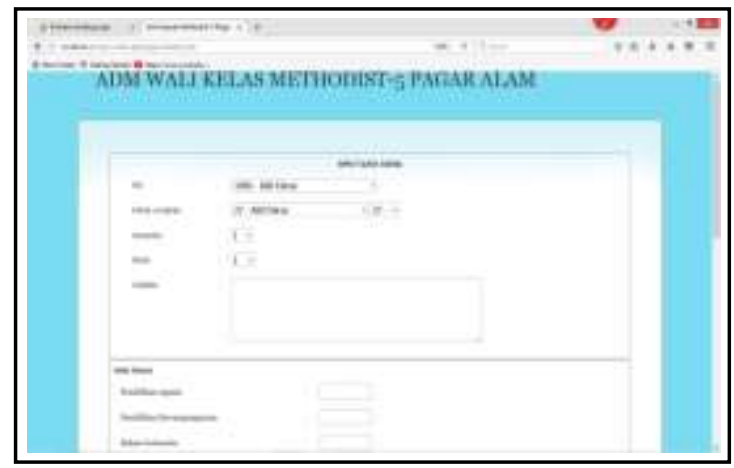

Gambar 14. Desain Halaman Input Nilai Siswa

\subsubsection{Desain Halaman Lihat Nilai Siswa}

Halaman lihat nilai siswa adalah halaman untuk melihat nilai siswa atas hasil evaluasi pembelajaran yang telah dicapai di sekolah per semester. Berikut gambar tampilannya :

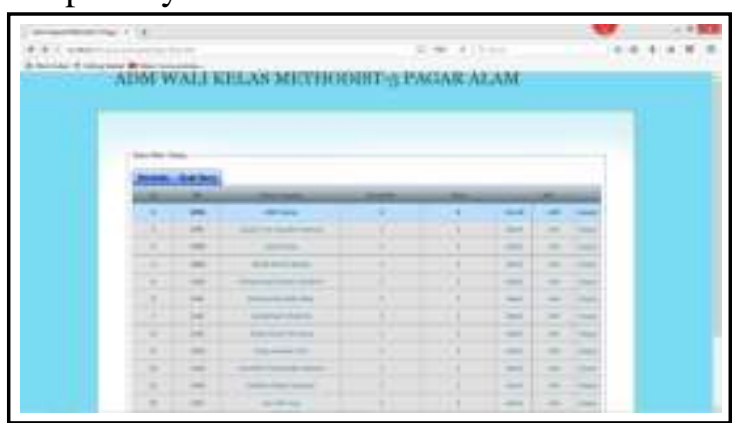

Gambar 15. Desain Halaman Lihat Nilai

\section{Siswa}

\section{SIMPULAN}

Dalam penulisan penelitian ini telah di uraikan bagaimana perancangan sistem dalam membangun Sistem Monitoring Siswa pada SD Methodist-5 Kota Pagar Alam, maka peneliti dapat menyimpulkan bahwa sistem monitoring siswa berbasis web, dapat membantu orang tua siswa dalam mengontrol proses hasil pembelajaran anak di sekolah 
tanpa harus datang langsung ke sekolah sehingga orang tua siswa memiliki kewajiban untuk melakukan monitoring siswa tersebut. Sistem monitoring siswa ini juga dapat membantu wali kelas dalam menyajikan data laporan hasil capaian pembelajaran siswa di sekolah.

\section{DAFTAR RUJUKAN}

Arief, M. Rudyanto. (2011). Pemrograman Web Dinamis Menggunakan PHP \& MySQL. Yogyakarta: ANDI Yogyakarta.

Desrianti. (2012). Media Pembelajaran Interaktif Bahasa Inggris Untuk Siswa Sekolah Dasar Kelas II. Program Studi Teknik Informatika Universitas Surakarta, 2.

Effendy, F., \& Nuqoba, B. (2016). penerapan framework bootsrap dalam pembangunan sistem informasi pengangkatan dan penjadwalan pegawai (studi kasus:rumah sakit bersalin buah delima sidoarjo). Jurnal Informatika Mulawarman, 2.

Kadir, Abdul. (2003). In A. Kadir, Pengenalan Sistem Informasi. Yogyakarta: ANDI Yogyakarta.

Kurnia, T., \& dkk. (2012). Perancangan Sistem Informasi Akademik Nilai Siswa Berbasis Web (Studi Kasus : SMK Ciledug Al-Musaddadiyah Garut). ipi180710, 1

Layuk, A., \& dkk. (2014). Sistem Informasi Pengolahan Nilai Raport Berbasis Web Sekolah Sosial Olahraga (Studi
Kasus: Real Madrid Foundation Samarinda). 176-484-1-PB, 1.

Madcoms. (2016). Pemrograman PHP dan MySQL. Yogyakarta: ANDI.

Nelly Indriani Widiastuti, R. S. (n.d.). Kajian Sistem Monitoring Dokumen Akreditasi Teknik Informatika Unikom. 07-miu-12-2-nely, 196.

Rohmat Taufik, ST., M.Kom. (2013). Sistem Informasi Manajemen. In S. M. Rohmat Taufik, Sistem Informasi Manajemen. Yogyakarta: Graha Ilmu. Rosa A.S, M.Shalahuddin. (2014). Rekayasa Perangkat Lunak. In M. Rosa A.S, Rekayasa Perangkat Lunak. Bandung: Informatika Bandung.

Wahana Komputer. (2013). Mobile Web Development with Adobe Dreamweaver CS6. In W. Komputer, Mobile Web Development with Adobe Dreamweaver CS6 (pp. 2-3). Semarang: ANDI. 